\title{
Notes on bats in the diets of Ghost Bats (Macroderma gigas: Megadermatidae) in the Pilbara region of Western Australia
}

\author{
A.N. Start ${ }^{1, *}$, N.L. McKenzie ${ }^{2}$ and R.D. Bullen ${ }^{3}$ \\ 129 Valley View Road, Roleystone, Western Australia 6111, Australia. \\ 2 Science and Conservation Division, Department of Biodiversity, Conservation and Attractions, \\ Locked Bag 104, Bentley Delivery Centre, Western Australia 6983, Australia. \\ 3 Bat Call WA Pty. Ltd., 43 Murray Drive, Hillarys, Western Australia 6025, Australia. \\ * Corresponding author: tonys@wn.com.au
}

\begin{abstract}
Claramunt et al. (2019), published a list of vertebrate prey items taken by Ghost Bats in the Pilbara Region of Western Australia but did not identify the bat wing bones that were contained in their samples. We identified those bones to extend (from four to nine species) knowledge of other bats consumed by Ghost Bats in the Pilbara showing that bats are an important component of their diets.
\end{abstract}

KEYWORDS: Ghost Bat, Diet, Pilbara

\section{INTRODUCTION}

The Ghost Bat (Macroderma gigas) is Australia's largest microchiropteran bat. Its status is listed as Vulnerable (C1) by the IUCN but is not listed in Western Australia, although its Conservation Priority status there is P1. (Woinarski et al. 2014). It is a carnivore that includes many small vertebrate species in a varied diet. Claramunt et al. (2019) published a list of vertebrate prey items recovered from refuse accumulations (middens) under Ghost Bat roosts and from DNA recovered from Ghost Bat scats in the Pilbara region of Western Australia (WA). Middens included material from large insects, amphibians, reptiles, birds and mammals, including bats. The bat material consisted of skulls, feet and wing bones. To identify mammal remains Claramunt et al. (2019) compared dentary and cranial items with vouchered specimens in the Western Australian Museum (WAM) collection. They did not use wing bones in the identification process. As we expected (from personal field observations) several other bats would have been included in the diets of Pilbara Ghost Bats, we sought to identify the wing bones in the midden material to extend knowledge of Pilbara Ghost Bat diets.

\section{METHODS}

Using a list of the microbats known from the inland Pilbara region of WA (McKenzie and Bullen 2009), we compared wing bones from the midden material with vouchered specimens in the WAM collections. The bones used were the radius (forearm) and the longest component of the 3rd metacarpal. As the proximal end of the forearm and the distal part of the metacarpal were often destroyed by the masticating Ghost Bats or otherwise damaged, only intact bones were used. Characters used were the lengths (in $\mathrm{mm}$ measured with a digital vernier caliper) and comparison of the 3-D shapes of the bones, particularly the curvature of the radius (which was assessed visually). Taxonomic nomenclature follows the 2019 version of the WAM checklist of terrestrial vertebrate fauna of WA (Western Australian Museum 2019). The entire collection of midden material studied by Claramunt and us has been deposited in the WAM.

\section{RESULTS}

The bats that were identified are listed in Table 1.

\section{DISCUSSION}

We added five bats to the list of species reported by Claramunt et al. (2019) and confirmed two of the four bat species reported by them but, being unable to separate (using wing bones) the two species of Taphozous we were unable to confirm their presence to species level. Nevertheless, we confirmed the genus Taphozous was present. Bat species reported in Ghost Bat diets from around Australia are listed in Table 2.

Although sample sizes are too small to quantify the ratios of different prey types, it is clear that other bats, in addition to small terrestrial mammals are commonly consumed by Ghost Bats. It is noteworthy that prey include species that utilise a wide variety of foraging strategies and airspaces (McKenzie and Bullen, 2009) and also that they include several species that commonly cohabit cave roosts with Ghost Bats in the Pilbara (Table 2). 
TABLE 1 Comparison of the families and species of bats identified from ghost bat midden material collected from the Pilbara region of WA and identified by Claramunt et al. (2019) and this study.

\begin{tabular}{|c|c|c|c|}
\hline Family & Species & Claramunt et al. & This study \\
\hline \multirow[t]{4}{*}{ Emballonuridae } & Saccolaimus flaviventris & No & Yes \\
\hline & Taphozous georgianus & Yes & $?$ \\
\hline & Taphozous hilli & Yes & $?$ \\
\hline & Taphozous sp. & N/A & Yes \\
\hline \multirow[t]{2}{*}{ Molossidae } & Austronomus australis & Yes & Yes \\
\hline & Ozimops lumsdenae & No & Yes \\
\hline Rhinonicteridae & Rhinonicteris aurantia & No & Yes \\
\hline \multirow[t]{3}{*}{ Vespertilionidae } & Chalinolobus gouldii & Yes & Yes \\
\hline & Nyctophilus daedalus & No & Yes \\
\hline & Vespadelus finlaysoni & No & Yes \\
\hline
\end{tabular}

TABLE 2 Bat species reported in ghost bat diets around Australia. Sources: 1) Claramunt et al. (2019); 2) Douglas (1976) (Pilbara region, WA); 3) Schultz (1986) (Pine Creek, Northern Territory); 4) Toop (1985) (central coastal Queensland); 5) This study (Pilbara region, WA); 6) Brent Johnston, personal communication, bat remains from a ghost bat midden identified with Alex Baynes (Pilbara region, WA); 7) R.D. Bullen, unpublished data (Pilbara region, WA).

Notes: * species known to cohabit cave roosts with Ghost Bats in the Pilbara

${ }^{1}$ as Tadarida australis; ${ }^{2}$ as Mormopterus beccarii; ${ }^{3}$ as Eptesicus finlaysoni.

\begin{tabular}{|c|c|c|c|}
\hline Family & Species & Roost site & Source reference \\
\hline \multirow[t]{3}{*}{ Embalonuridae } & Saccolaimus flaviventris & Tree hollows & 5 \\
\hline & Taphozous georgianus* & Caves & $1,2,4$ \\
\hline & Taphozous hilli* & Caves & 1 \\
\hline Hipposiderideae & Hipposideros ater & Caves & 3 \\
\hline \multirow[t]{2}{*}{ Molossidae } & Austronomus australis & Tree hollows & $1,5,6^{1}$ \\
\hline & Ozimops lumsdenae & Tree hollows & $5,6^{2}$ \\
\hline Rhinolophidae & Rhinolophus megaphylus & Caves & 4 \\
\hline Rhinonicteridae & Rhinonicteris aurantia* & Caves & 5,7 \\
\hline \multirow[t]{5}{*}{ Vespertilionidae } & Chalinolobus gouldii & Tree hollows & 1,5 \\
\hline & Nyctophilus daedalus & Vegetation & 5 \\
\hline & Nyctophilus geoffroyi & Vegetation & 6 \\
\hline & Miniopterus australis & Caves & $2,3,4$ \\
\hline & Vespadelus finlaysoni* & Caves & $2^{3}, 3^{3}, 5,6^{3}$ \\
\hline
\end{tabular}




\section{ACKNOWLEDGEMENTS}

We thank Peter Mawson for making the midden material available to us, Kenny Travouillon of the Western Australian Museum for allowing us access to the museum's collections and for facilitating our work there and Brent Johnson for providing us with his list of species identified with Alex Baynes at the WAM. We also thank two anonymous referees for their very useful comments.

\section{REFERENCES}

Claramunt, A.M.A., White, E.N., Bunce, M., O'Connell, M., Bullen, R.D. and Mawson P.R. (2019). Determination of the diet of the Ghost Bat (Macroderma gigas) in the Pilbara region of Western Australia from prey remains and DNA metabarcoding. Australian Journal of Zoology 66: 195-200.

Douglas A.M. (1976). The natural history of the Ghost Bat, Macroderma gigas, (Microchiroptera, Megadermatidae) in Western Australia. Western Australian Naturalist 10: 125-137.

Johnston, M., Herrod, A., Little, N., Bould, L., and Gigliotti, F. (2015). An opportunistic observation of Ghost Bat (Macroderma gigas) predation on six bird species within
Karijini National Park. Journal of the Royal Society of Western Australia 98: 89-91.

McKenzie, N.L. and Bullen, R.D. (2009). The echolocation calls, habitat relationships, foraging niches and communities of Pilbara microbats. Records of the Western Australian Museum, Supplement 78(1): 123-155. doi: 10.18195/issn.0313-122x.78(1).2009.123-155

Schulz, M. (1986). Vertebrate prey of the Ghost Bat, Macroderma gigas, at Pine Creek, Northern Territory. Macroderma 2: 59-62.

Toop, G. J. (1985). Habitat requirements, survival strategies and ecology of the Ghost Bat, Macroderma gigas Dobson (Microchiroptera, Megadermatidae) in central coastal Queensland. Macroderma 1: 37-41.

Western Australian Museum (2019). Checklist of the Terrestrial Vertebrate Fauna of Western Australia. Available at http:// museum.wa.gov.au/research/departments/terrestrialzoology/checklist-terrestrial-vertebrate-fauna-westernaustralia [Accessed 24 August 2019].

Woinarski J.C.Z., Burbidge A.A. and Harrison P.L. (2014). The action plan for Australian mammals. CSIRO Publishing, Collingwood.

MANUSCRIPT RECEIVED 21 OCTOBER 2019; ACCEPTED 15 NOVEMBER 2019. 